\title{
Article
}

\section{Alumina-carbon nanotube supports for sulfur-resistant regenerable Pt-based catalysts in $\mathrm{NO}_{x}$ reduction}

\author{
Lilong Jiang *, Yuling Wang, Xian Liu, Yanning Cao, Kemei Wei \\ National Engineering Research Center of Chemical Fertilizer Catalyst, Fuzhou University, Fuzhou 350002, Fujian, China
}

\section{A R T I C L E I N F O}

\section{Article history:}

Received 14 September 2013

Accepted 21 October 2013

Published 20 December 2013

\section{Keywords:}

Carbon nanotube

Oxynitride elimination

Sulfur dioxide poisoning

Regeneration

\begin{abstract}
A B S T R A C T
Alumina-carbon nanotube $\left(\mathrm{Al}_{2} \mathrm{O}_{3}\right.$-CNT) supports were prepared by the decomposition of acetylene on $\mathrm{Al}_{2} \mathrm{O}_{3}$. The subsequent impregnation of $\mathrm{Pt}$ and $\mathrm{Ba}$ yielded $\mathrm{Pt} / \mathrm{Ba} / \mathrm{Al}_{2} \mathrm{O}_{3}-\mathrm{CNT}$. Pt/Ba/ $/ \mathrm{Al}_{2} \mathrm{O}_{3}-\mathrm{CNT}$ was characterized by X-ray diffraction, scanning and transmission electron microscopies, $\mathrm{N}_{2}$ physisorption, X-ray photoelectron spectroscopy, and in-situ diffuse reflectance infrared Fourier transform spectroscopy (DRIFTS). The relationship between the structure and properties of $\mathrm{Pt} / \mathrm{Ba} / \mathrm{Al}_{2} \mathrm{O}_{3}-\mathrm{CNT}$ was investigated. $\mathrm{Pt} / \mathrm{Ba} / \mathrm{Al}_{2} \mathrm{O}_{3}-\mathrm{CNT}$ exhibited much higher resistance to $\mathrm{SO}_{2}$ poisoning and better regeneration ability than $\mathrm{Pt} / \mathrm{Ba} / \mathrm{Al}_{2} \mathrm{O}_{3}$, during $\mathrm{NO}_{x}$ reduction in the presence of $\mathrm{SO}_{2}$. In-situ DRIFTS spectra suggested that $\mathrm{SO}_{2}$ had no effect on the $\mathrm{NO}_{x}$ storage and reduction process.
\end{abstract}

(C) 2013, Dalian Institute of Chemical Physics, Chinese Academy of Sciences. Published by Elsevier B.V. All rights reserved.

\section{Introduction}

Nitrogen oxides $\left(\mathrm{NO}_{x}\right)$ are emitted from stationary sources and automobiles, and pose a threat to environmental and human health [1]. Increasing car numbers and $\mathrm{NO}_{x}$ emission regulations have encouraged the development of technology to eliminate $\mathrm{NO}_{x}$ from lean-burn exhaust. Traditional three-way catalysts are inefficient for $\mathrm{NO}_{x}$ abatement under lean-burn conditions [2,3]. $\mathrm{NO}_{x}$ storage-reduction (NSR) is a promising technology for $\mathrm{NO}_{x}$ removal in lean-burn engines. NSR catalysts usually contain precious metals, alkali or alkaline earth metals, and high surface area supports [3]. $\mathrm{Pt} / \mathrm{Ba} / \mathrm{Al}_{2} \mathrm{O}_{3}$ is a model NSR catalyst, and has been the subject of considerable experimental and theoretical investigation [4-7]. One of its disadvantages is deactivation due to sulfur poisoning [8]. Sulfur present in fuel and lubricants can poison $\mathrm{Pt} / \mathrm{Ba} / \mathrm{Al}_{2} \mathrm{O}_{3}$ by forming stable barium sulfate, which blocks storage sites and platinum surfaces. The recovery of the catalyst by sulfur removal requires high temperature, and successive regeneration usually causes sintering of precious metals and storage materials. The solid state reaction between $\mathrm{Ba}$ and $\mathrm{Al}_{2} \mathrm{O}_{3}$ may also result in the formation of inactive $\mathrm{BaAlO}_{2}$ [9].

Improving the sulfur resistance and thermal stability of NSR catalysts has received much attention. Supports significantly affect the catalytic activity, and using composite supports can improve NSR performance. For example, blending $\mathrm{TiO}_{2}$ and $\mathrm{Al}_{2} \mathrm{O}_{3}$ can suppress sulfur deposition, and enhance the $\mathrm{NO}_{x}$ storage capacity of sulfur-aged catalysts [10-12]. An acceptable balance between thermal resistance and sulfur tolerance can be achieved in $\mathrm{TiO}_{2}-\mathrm{ZrO}_{2}$ supports, leading to an increased $\mathrm{NO}_{x}$ storage ability of sulfur-aged NSR catalysts [13].

Carbon nanotubes (CNTs) have been extensively used as supports in catalytic reactions, because of their favorable structure and unique properties [14,15]. The large surface area and confinement effect in CNTs may prevent the agglomeration of metal components, resulting in high catalytic activity [16,17].

\footnotetext{
* Corresponding author. Tel: +86-591-83731234-8201; Fax: +86-591-83707796; E-mail: jll@fzu.edu.cn This work was supported by the National Natural Science Foundation of China (21073039) and the Natural Science Foundation of Fujian Province (2013J05025).
}

DOI: 10.1016/S1872-2067(12)60745-1 | http://www.sciencedirect.com/science/journal/18722067 | Chin. J. Catal., Vol. 34, No. 12, December 2013 
Luo et al. [18] attributed the higher NO conversion over $\mathrm{Rh} / \mathrm{CNTs}$ than $\mathrm{Rh} / \gamma-\mathrm{Al}_{2} \mathrm{O}_{3}$ to the superior stabilization of $\mathrm{Rh}^{0}$ on the CNTs. Iron-copper oxides supported on $\mathrm{TiO}_{2}$ and CNTs reportedly exhibit high resistance against sulfur poisoning, and excellent $\mathrm{NO}_{x}$ elimination performance at low temperature [19]. In our continuous effort to develop sulfur-resistant NSR catalysts [20], herein we introduce CNTs into $\mathrm{Pt} / \mathrm{Ba} / \mathrm{Al}_{2} \mathrm{O}_{3}$ to form a Pt/Ba/ $\mathrm{Al}_{2} \mathrm{O}_{3}$-CNTs catalyst. Its structure, NSR performance, and the effects of $\mathrm{SO}_{2}$ concentration and regeneration time on NSR are investigated. The role of CNTs in the $\mathrm{Pt} / \mathrm{Ba} / \mathrm{Al}_{2} \mathrm{O}_{3}-\mathrm{CNTs}$ catalyst is also investigated.

\section{Experimental}

\subsection{Preparation of Pt/Ba/Al $\mathrm{O}_{3}-\mathrm{CNTs}$ and $\mathrm{Pt} / \mathrm{Ba} / \mathrm{Al}_{2} \mathrm{O}_{3}$}

Alumina was synthesized according to the literature methods [21]. CNTs were prepared by chemical vapor deposition (CVD). An aqueous solution of molybdenum nitrate was impregnated on $\mathrm{Al}_{2} \mathrm{O}_{3}$, subsequently placed in a porcelain boat in a tube reactor, pretreated in $\mathrm{H}_{2}$ at $500{ }^{\circ} \mathrm{C}$ for $2 \mathrm{~h}$, and heated to $750{ }^{\circ} \mathrm{C}$ in an Ar flow. A gas mixture of $\mathrm{C}_{2} \mathrm{H}_{2}(20 \mathrm{~mL} / \mathrm{min})$ and $\mathrm{H}_{2}$ (100 $\mathrm{mL} / \mathrm{min}$ ) was subsequently introduced for $0.5 \mathrm{~h}$, followed by an $\mathrm{H}_{2}$ flow for $2 \mathrm{~h}$ to remove excess carbon, before cooling to room temperature in Ar. The product was purified by soaking in $30 \% \mathrm{H}_{2} \mathrm{O}_{2}$ for $48 \mathrm{~h}$, dried at $100{ }^{\circ} \mathrm{C}$ overnight, and calcined in air at $550{ }^{\circ} \mathrm{C}$ for $4 \mathrm{~h}$ to yield $\mathrm{Al}_{2} \mathrm{O}_{3}$-CNTs.

$\mathrm{Ba}(16 \%)$ and $\mathrm{Pt}(1 \%)$ were dispersed on $\mathrm{Al}_{2} \mathrm{O}_{3}$-CNTs by conventional impregnation, using aqueous $\mathrm{Ba}(\mathrm{OAc})_{2}$ and $\mathrm{H}_{2} \mathrm{PtCl}_{6} \cdot 6 \mathrm{H}_{2} \mathrm{O}$ solutions, respectively. The impregnated sample was then dried at $120^{\circ} \mathrm{C}$ overnight, and calcined in air at $500{ }^{\circ} \mathrm{C}$ for $4 \mathrm{~h}$. The obtained catalyst was denoted as $\mathrm{Pt} / \mathrm{Ba} /$ $\mathrm{Al}_{2} \mathrm{O}_{3}$-CNTs. For comparison, $\mathrm{Pt} / \mathrm{Ba} / \mathrm{Al}_{2} \mathrm{O}_{3}$ with the same amount of $\mathrm{Ba}$ and $\mathrm{Pt}$ was also prepared by the same procedure as $\mathrm{Pt} / \mathrm{Ba} / \mathrm{Al}_{2} \mathrm{O}_{3}-\mathrm{CNTs}$, except that $\mathrm{Al}_{2} \mathrm{O}_{3}$ was used as the support.

\subsection{Characterization}

Powder X-ray diffraction (XRD) was performed on a RigakuDMax 2500PC diffractometer, using $\mathrm{Cu}-K_{\alpha}$ radiation $(\lambda=$ $0.15406 \mathrm{~nm})$. XRD patterns were recorded at $2 \theta=10^{\circ}-80^{\circ}$. N2 physisorption measurements were carried out using a Micromeritics ASAP 2020 apparatus. Samples were degassed in vacuo at $180{ }^{\circ} \mathrm{C}$ for at least $6 \mathrm{~h}$ before measurements. Pore size distributions were obtained from the isotherm adsorption branch, using the Barrett Joyner Halenda (BJH) model. X-ray photoelectron spectroscopy (XPS) was performed on a Physical Electronics Quantum 2000 instrument, equipped with a monochromatic Al- $K_{\alpha}$ source ( $\left.K_{\alpha}=1486.6 \mathrm{eV}\right)$ and a charge neutralizer. Transmission electron microscopy (TEM) was performed on a FEI Tecnai G ${ }^{2}$ F20 microscope, operated at $200 \mathrm{kV}$. Scanning electron microscopy (SEM) was performed on a Hitachi $\mathrm{S}-4800$ microscope, operated at $5.0 \mathrm{kV}$. Inductively coupled plasma (ICP) spectroscopy was performed on a JY Ultima2 spectrometer.

In-situ diffuse reflectance infrared Fourier transform spec- tra (DRIFTS) were recorded on a Nicolet Nexus FT-IR spectrometer over the $4000-650 \mathrm{~cm}^{-1}$ range, from 32 scans at 4 $\mathrm{cm}^{-1}$ resolution. Approximately $50 \mathrm{mg}$ of sample in a DRIFTS cell was pretreated with $\mathrm{He}$ at the testing temperature for 30 min, and the recorded spectrum was taken as the background. A gas mixture of NO $\left(500 \times 10^{-6}\right)$ and $2 \% \mathrm{O}_{2}$ was introduced into the sample cell, and spectra were collected. An additional $\mathrm{SO}_{2}\left(100 \times 10^{-6}\right)$ was then introduced into the sample cell, and spectra were collected to follow the evolution of different surface species. The regeneration of $\mathrm{Pt} / \mathrm{Ba} / \mathrm{Al}_{2} \mathrm{O}_{3}$-CNTs was performed with $3.5 \% \mathrm{H}_{2}-96.5 \% \mathrm{Ar}$, after samples were exposed to $\mathrm{SO}_{2}\left(100 \times 10^{-6}\right)$ at $400{ }^{\circ} \mathrm{C}$ for $1 \mathrm{~h}$. DRIFTS spectra were recorded after different time. The final differential sample spectra were calculated using the Kubelka-Munk function.

\subsection{Catalytic activity measurements}

Catalytic tests were carried out in a stainless steel fixed bed flow reactor ( $8 \mathrm{~mm}$ internal diameter). Prior to each test, the sample ( $0.5 \mathrm{~g}$ ) was pretreated in a $\mathrm{N}_{2}$ flow ( $30 \mathrm{~mL} / \mathrm{min}$ ) at 500 ${ }^{\circ} \mathrm{C}$ for $1 \mathrm{~h}$ to remove any adsorbed species, and then cooled to the test temperature. The feed gas was introduced using mass-flow controllers, at a total flow rate of $600 \mathrm{ml} / \mathrm{min}$. The $\mathrm{NO}_{x}$ concentration was measured using an on-line chemiluminescence NO- $\mathrm{NO}_{2}-\mathrm{NO}_{x}$ analyzer (model 42i-HL, Thermo Scientific). After measurement, the catalysts were sulfur-aged by exposing to a feed gas containing $\mathrm{SO}_{2}\left(0-250 \times 10^{-6}\right)$ for $45 \mathrm{~min}$. Sulfur-aged $\mathrm{Pt} / \mathrm{Ba} / \mathrm{Al}_{2} \mathrm{O}_{3}-\mathrm{CNTs}$ and $\mathrm{Pt} / \mathrm{Ba} / \mathrm{Al}_{2} \mathrm{O}_{3}$ were denoted as $\mathrm{Pt} / \mathrm{Ba} / \mathrm{Al}_{2} \mathrm{O}_{3}-\mathrm{CNTs}-\mathrm{SO}_{2}$ and $\mathrm{Pt} / \mathrm{Ba} / \mathrm{Al}_{2} \mathrm{O}_{3}-\mathrm{SO}_{2}$, respectively. The regeneration ability of the sulfur-aged samples was tested in $3.5 \% \mathrm{H}_{2}$ and $96.5 \%$ Ar at $400{ }^{\circ} \mathrm{C}$.

\section{Results and discussion}

\subsection{SEM and TEM results}

The morphology of $\mathrm{Al}_{2} \mathrm{O}_{3}$-CNTs is shown in Fig. 1. The SEM image revealed that the CNTs were coiled Fig. 1(a). A typical nanotube was analyzed by TEM Fig. 1(b), and its outer and inner diameters were $c a .48$ and $43 \mathrm{~nm}$, respectively. A few alumina particles were also observed in the SEM image.

\subsection{Textural properties}

The textural properties of the supports and corresponding catalysts are summarized in Table 1 . The specific surface area of $\mathrm{Al}_{2} \mathrm{O}_{3}$-CNTs was $416 \mathrm{~m}^{2} / \mathrm{g}$, which was much larger than that

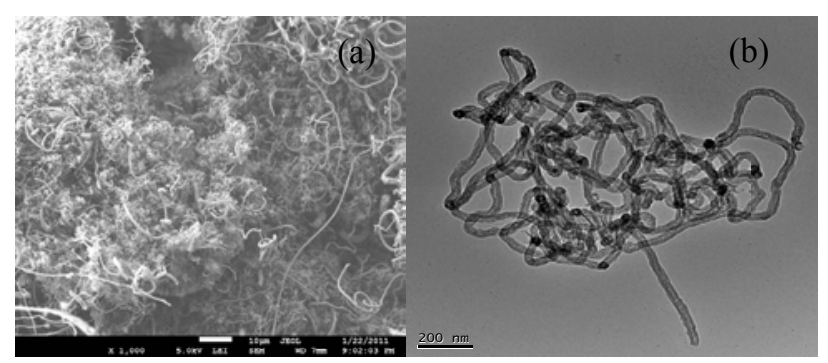

Fig. 1. SEM (a) and TEM (b) images of $\mathrm{Al}_{2} \mathrm{O}_{3}$-CNTs. 
Table 1

Textural properties of the samples.

\begin{tabular}{lccc}
\hline Sample & $\begin{array}{c}\text { BET surface area Pore volume } \\
\left(\mathrm{m}^{2} / \mathrm{g}\right)\end{array}$ & $\begin{array}{c}\text { Average pore radius } \\
(\mathrm{cm} / \mathrm{g})\end{array}$ \\
\hline $\mathrm{Al}_{2} \mathrm{O}_{3}$ & 266 & 0.56 & 4.87 \\
$\mathrm{Al}_{2} \mathrm{O}_{3}-\mathrm{CNTs}$ & 416 & 0.66 & 6.30 \\
$\mathrm{Pt} / \mathrm{Ba} / \mathrm{Al}_{2} \mathrm{O}_{3}$ & 216 & 0.41 & 6.26 \\
$\mathrm{Pt} / \mathrm{Ba} / \mathrm{Al}_{2} \mathrm{O}_{3}-\mathrm{CNTs}$ & 389 & 0.62 & 3.54 \\
\hline
\end{tabular}

of $\mathrm{Pt} / \mathrm{Ba} / \mathrm{Al}_{2} \mathrm{O}_{3}$. The specific surface area and pore volume of $\mathrm{Pt} / \mathrm{Ba} / \mathrm{Al}_{2} \mathrm{O}_{3}-\mathrm{CNTs}$ and $\mathrm{Pt} / \mathrm{Ba} / \mathrm{Al}_{2} \mathrm{O}_{3}$ decreased after impregnation by $\mathrm{Pt}$ and $\mathrm{Ba}$, while their average pore radii increased. ICP analyses indicated that their Pt and Ba contents were 0.86\% and $10.84 \%$, respectively, which were lower than their loading amounts. The content of molybdenum $(0.00035 \%)$ was negligible, suggesting that molybdenum was completely removed during CNT preparation.

\subsection{NSR performance}

The NSR performance of $\mathrm{Pt} / \mathrm{Ba} / \mathrm{Al}_{2} \mathrm{O}_{3}$-CNTs was initially evaluated using the relative $\mathrm{NO}_{x}$ storage capacity and $\mathrm{NO}_{x}$ conversion, in the absence of $\mathrm{SO}_{2}$. As shown in Fig. 2. the relative $\mathrm{NO}_{x}$ storage capacity and $\mathrm{NO}_{x}$ conversion over $\mathrm{Pt} / \mathrm{Ba} /$ $\mathrm{Al}_{2} \mathrm{O}_{3}$-CNTs were similar to those over $\mathrm{Pt} / \mathrm{Ba} / \mathrm{Al}_{2} \mathrm{O}_{3}$. Temperature had no obvious effect on the relative $\mathrm{NO}_{x}$ storage capacity ( 2 min), which was $>90 \%$ over the range of tested tempera-

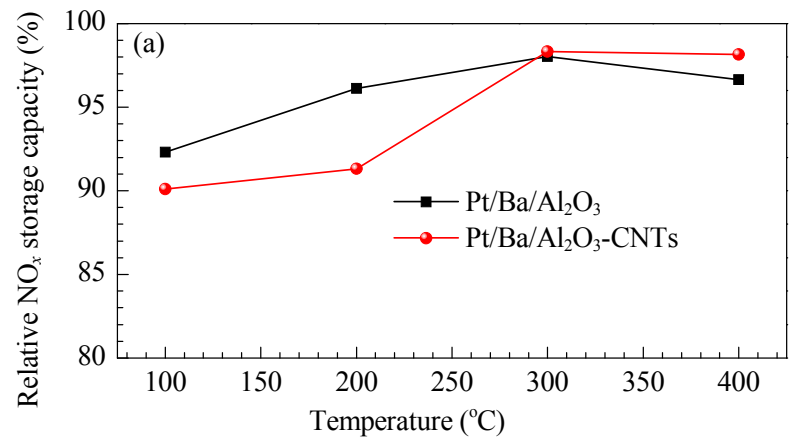

Fig. 2. Relative $\mathrm{NO}_{x}$ storage capacity (a) and $\mathrm{NO}_{x}$ conversion (b) over $\mathrm{Pt} / \mathrm{Ba} / \mathrm{Al}_{2} \mathrm{O}_{3}-\mathrm{CNTs}$ and $\mathrm{Pt} / \mathrm{Ba} / \mathrm{Al}_{2} \mathrm{O}_{3}$ catalysts.

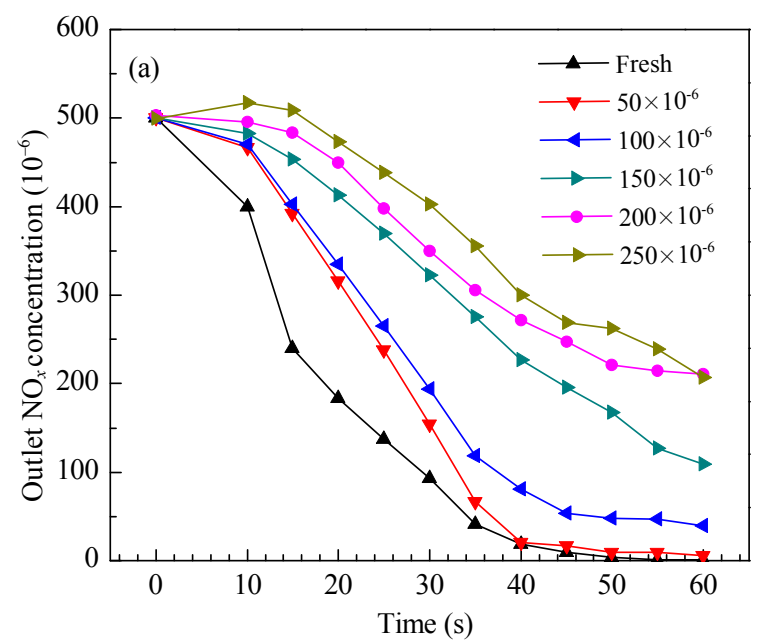

Fig. 3. Outlet $\mathrm{NO}_{x}$ concentration at $300{ }^{\circ} \mathrm{C}$ for the exposure of $\mathrm{Pt} / \mathrm{Ba} / \mathrm{Al}_{2} \mathrm{O}_{3}-\mathrm{CNTs}(\mathrm{a})$ and $\mathrm{Pt} / \mathrm{Ba} / \mathrm{Al}_{2} \mathrm{O}_{3}$ catalysts (b) to different $\mathrm{SO} \mathrm{C}_{2}$ concentrations.

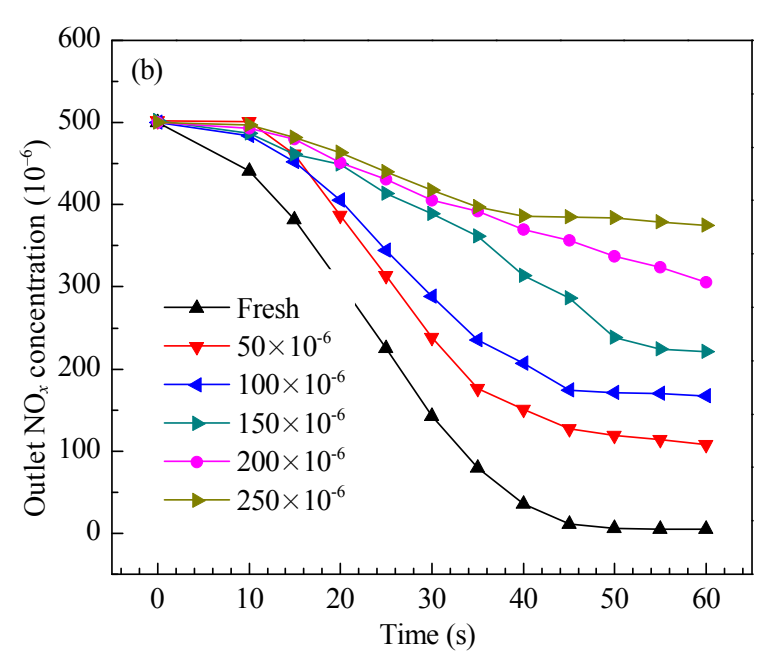

tures. However, $\mathrm{NO}_{x}$ conversion was enhanced as the temperature increased from 200 to $350{ }^{\circ} \mathrm{C}$. For example, $\mathrm{NO}_{x}$ conversions at $200{ }^{\circ} \mathrm{C}$ and $350{ }^{\circ} \mathrm{C}$ were $22.89 \%$ and $91.29 \%$, respectively.

The effect of sulfur poisoning on the $\mathrm{NO}_{x}$ reduction over $\mathrm{Pt} / \mathrm{Ba} / \mathrm{Al}_{2} \mathrm{O}_{3}-\mathrm{CNTs}$ and $\mathrm{Pt} / \mathrm{Ba} / \mathrm{Al}_{2} \mathrm{O}_{3}$ was investigated in the presence of $\mathrm{SO}_{2}\left(0-250 \times 10^{-6}\right)$, as shown in Fig. 3, When fresh $\mathrm{Pt} / \mathrm{Ba} / \mathrm{Al}_{2} \mathrm{O}_{3}-\mathrm{CNTs}$ and $\mathrm{Pt} / \mathrm{Ba} / \mathrm{Al}_{2} \mathrm{O}_{3}$ were reduced by $3.5 \% \mathrm{H}_{2}$ at $300{ }^{\circ} \mathrm{C}$ for $1 \mathrm{~min}$, the outlet $\mathrm{NO}_{x}$ concentrations were $0.89 \times$ $10^{-6}$ and $2.54 \times 10^{-6}$, respectively. When $\mathrm{SO}_{2}\left(50 \times 10^{-6}\right)$ was introduced into feed gas, the outlet $\mathrm{NO}_{x}$ concentration increased to $5.26 \times 10^{-6}$ and $107 \times 10^{-6}$, respectively, suggesting that $\mathrm{Pt} / \mathrm{Ba} / \mathrm{Al}_{2} \mathrm{O}_{3}-\mathrm{CNTs}$ and $\mathrm{Pt} / \mathrm{Ba} / \mathrm{Al}_{2} \mathrm{O}_{3}$ were deactivated by $\mathrm{SO}_{2}$. The deactivation rate was related to the $\mathrm{SO}_{2}$ concentration. When the $\mathrm{SO}_{2}$ concentration was increased to $250 \times 10^{-6}$, a significant decrease in $\mathrm{NO}_{x}$ reduction rate was observed, and the outlet $\mathrm{NO}_{x}$ concentrations for $\mathrm{Pt} / \mathrm{Ba} / \mathrm{Al}_{2} \mathrm{O}_{3}-\mathrm{CNTs}$ and $\mathrm{Pt} / \mathrm{Ba} / \mathrm{Al}_{2} \mathrm{O}_{3}$ reached $207 \times 10^{-6}$ and $375 \times 10^{-6}$, respectively. $\mathrm{SO}_{2}$ had a more pronounced effect on $\mathrm{Pt} / \mathrm{Ba} / \mathrm{Al}_{2} \mathrm{O}_{3}$ than $\mathrm{Pt} / \mathrm{Ba} / \mathrm{Al}_{2} \mathrm{O}_{3}$-CNTs. Deactivation from $\mathrm{SO}_{2}$ was ascribed to the strong affinity of barium with $\mathrm{SO}_{3}$. This formed stable barium sulfate [22], and restricted the contact between $\mathrm{Pt}$ and $\mathrm{NO}_{2}$. Literature reports $[16,17]$ indicate that CNTs exhibit good $\mathrm{NO}_{x}$ adsorption and oxidation resistance. The oxidation of $\mathrm{SO}_{2}$ to $\mathrm{SO}_{3}$ may have been inhibited in the $\mathrm{SO}_{2}$ atmosphere, which decreased the formation of $\mathrm{BaSO}_{4}$ during $\mathrm{NO}_{x}$ reduction.

NSR catalyst regeneration is related to time, so the effect of

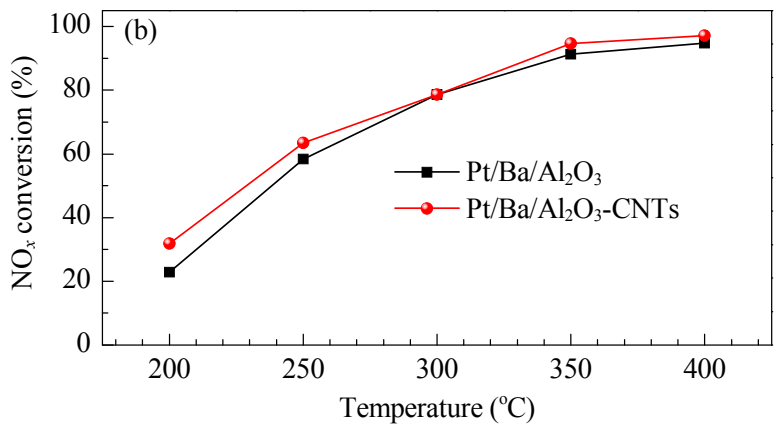



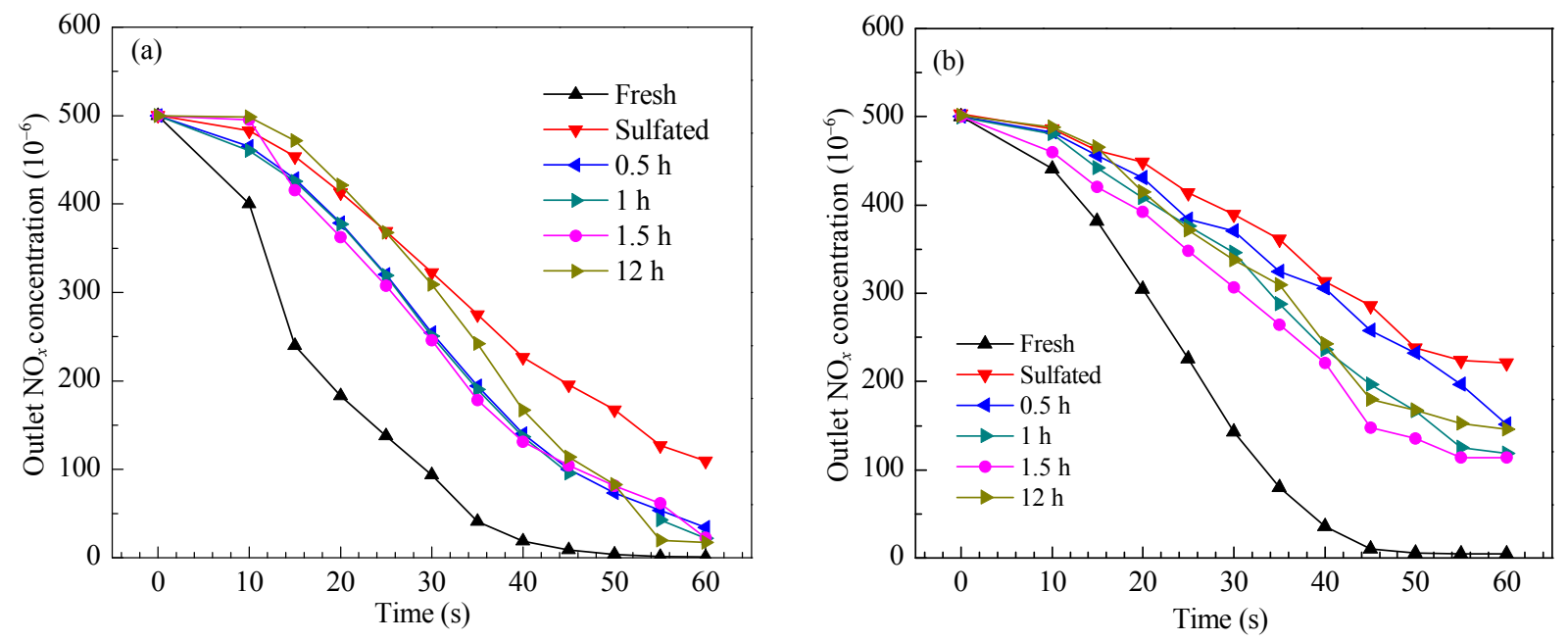

Fig. 4. Outlet $\mathrm{NO}_{x}$ concentration at $300{ }^{\circ} \mathrm{C}$ for fresh, sulfur-aged $\mathrm{SO}_{2}\left(150 \times 10^{-6}\right)$ and regenerated $\mathrm{Pt} / \mathrm{Ba} / \mathrm{Al}_{2} \mathrm{O}_{3}-\mathrm{CNTs}(\mathrm{a})$ and $\mathrm{Pt} / \mathrm{Ba} / \mathrm{Al} \mathrm{O}_{3}$ catalysts $(\mathrm{b})$.

regeneration time on the sulfur-aged catalysts was investigated. As shown in Fig. 4, the $\mathrm{NO}_{x}$ reduction ability could be somewhat recovered after the sulfur-aged samples were regenerated. For example, the outlet $\mathrm{NO}_{x}$ concentrations were $22.3 \times 10^{-6}$ and $118 \times 10^{-6}$, respectively, after $\mathrm{Pt} / \mathrm{Ba} /$ $\mathrm{Al}_{2} \mathrm{O}_{3}-\mathrm{CNTs}$ and $\mathrm{Pt} / \mathrm{Ba} / \mathrm{Al}_{2} \mathrm{O}_{3}$ were sulfur-aged by $\mathrm{SO}_{2}(150 \times$ $10^{-6}$ ) and then reduced by $3.5 \% \mathrm{H}_{2}$ for $1 \mathrm{~h}$. Pt/Ba/ $/ \mathrm{Al}_{2} \mathrm{O}_{3}-\mathrm{CNTs}$ exhibited a higher resistance to $\mathrm{SO}_{2}$ poisoning and better regeneration ability than $\mathrm{Pt} / \mathrm{Ba} / \mathrm{Al}_{2} \mathrm{O}_{3}$.

\subsection{XRD results}

To further investigate the effect of sulfur poisoning on $\mathrm{Pt} / \mathrm{Ba} / \mathrm{Al}_{2} \mathrm{O}_{3}-\mathrm{CNTs}$ and $\mathrm{Pt} / \mathrm{Ba} / \mathrm{Al}_{2} \mathrm{O}_{3}$, fresh and sulfur-aged samples were investigated by XRD and XPS. XRD patterns indicated the superior sulfur tolerance of $\mathrm{Pt} / \mathrm{Ba} / \mathrm{Al}_{2} \mathrm{O}_{3}-\mathrm{CNTs}$. Figure 5 shows that after fresh samples were treated by $\mathrm{SO}_{2}(150 \times$ $10^{-6}$ ) for $(0.5 \mathrm{~h})$, strong peaks at $2 \theta=26.0^{\circ}, 28.7^{\circ}$, and $42.6^{\circ}$ (characteristic of $\mathrm{BaSO}_{4}$ ) were observed in the XRD pattern of $\mathrm{Pt} / \mathrm{Ba} / \mathrm{Al}_{2} \mathrm{O}_{3}-\mathrm{SO}_{2}$ [12]. Only weak $\mathrm{BaSO}_{4}$ peaks were observed in that of $\mathrm{Pt} / \mathrm{Ba} / \mathrm{Al}_{2} \mathrm{O}_{3}-\mathrm{CNTs}-\mathrm{SO}_{2}$. No Pt species peaks were

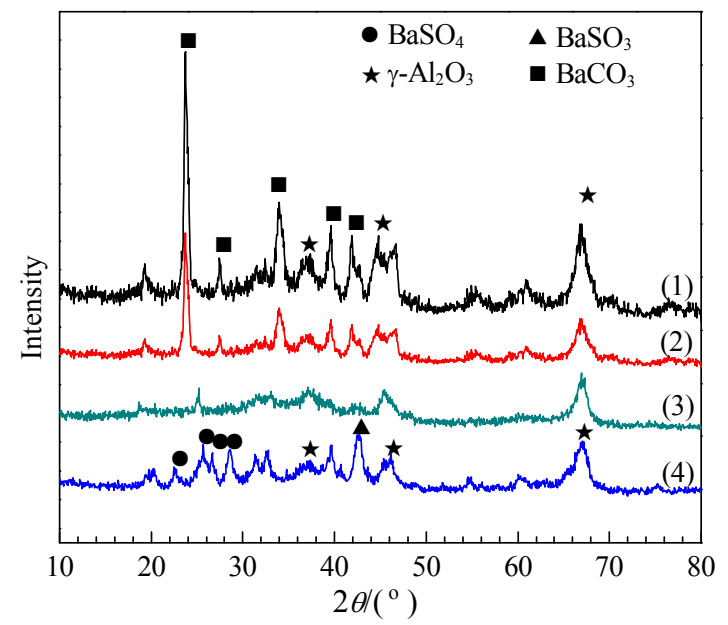

Fig. 5. XRD patterns for $\mathrm{Pt} / \mathrm{Ba} / \mathrm{Al}_{2} \mathrm{O}_{3}-\mathrm{CNTs}(1), \mathrm{Pt} / \mathrm{Ba} / \mathrm{Al}_{2} \mathrm{O}_{3}-\mathrm{CNTs}-\mathrm{SO}_{2}$ (2), $\mathrm{Pt} / \mathrm{Ba} / \mathrm{Al}_{2} \mathrm{O}_{3}(3)$, and $\mathrm{Pt} / \mathrm{Ba} / \mathrm{Al}_{2} \mathrm{O}_{3}-\mathrm{SO}_{2}$ (4). observed, suggesting that Pt species were either finely dispersed or too small to be detected by XRD [23].

\subsection{XPS results}

To evaluate the sulfur content accumulated on the catalyst surface, $\mathrm{SO}_{2}$-treated and $\mathrm{H}_{2}$-regenerated catalysts were investigated by XPS. The XPS peak at $c a$. $169.4 \mathrm{eV}$ was assigned to sulfate, arising from the uptake of sulfur during $\mathrm{SO}_{2}$ exposure (Fig. 6) [4]. The sulfur content of $\mathrm{Pt} / \mathrm{Ba} / \mathrm{Al}_{2} \mathrm{O}_{3}-\mathrm{CNTs}_{-} \mathrm{SO}_{2}$ was lower than that of $\mathrm{Pt} / \mathrm{Ba} / \mathrm{Al}_{2} \mathrm{O}_{3}-\mathrm{SO}_{2}$ (Table 2). Sulfur peaks were clearly observed in the XPS spectrum of $\mathrm{Pt} / \mathrm{Ba}$ / $\mathrm{Al}_{2} \mathrm{O}_{3}-\mathrm{SO}_{2}-\mathrm{H}_{2}$, but had largely disappeared in the spectrum of $\mathrm{Pt} / \mathrm{Ba} / \mathrm{Al}_{2} \mathrm{O}_{3}-\mathrm{CNTs}-\mathrm{SO}_{2}-\mathrm{H}_{2}$. These results indicated the higher sulfur tolerance and regeneration ability of $\mathrm{Pt} / \mathrm{Ba} / \mathrm{Al}_{2} \mathrm{O}_{3}-\mathrm{CNTs}$, compared with $\mathrm{Pt} / \mathrm{Ba} / \mathrm{Al}_{2} \mathrm{O}_{3}$.

\subsection{In-situ DRIFTS results}

To further investigate the effect of $\mathrm{SO}_{2}$ on NSR in $\mathrm{Pt} / \mathrm{Ba} /$ $\mathrm{Al}_{2} \mathrm{O}_{3}$-CNTs, in-situ DRIFTS experiments were carried out. Fig-

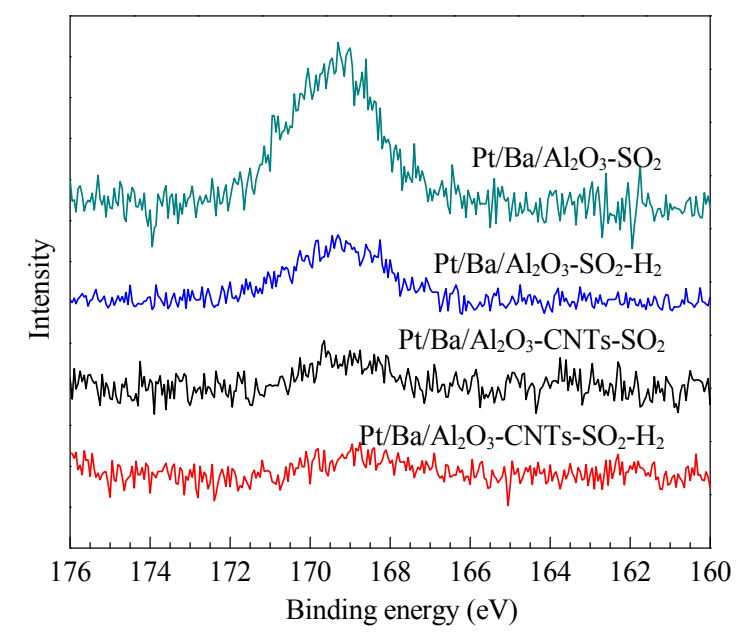

Fig. 6. XPS S $2 p$ spectra of $\mathrm{Pt} / \mathrm{Ba} / \mathrm{Al}_{2} \mathrm{O}_{3}$-CNTs and $\mathrm{Pt} / \mathrm{Ba} / \mathrm{Al}_{2} \mathrm{O}_{3}$, after being sulfur-aged $\mathrm{SO}_{2}\left(150 \times 10^{-6}\right)$ and regenerated. 
Table 2

Surface sulfur content determined by XPS.

\begin{tabular}{lc}
\hline Sample & $\mathrm{S} 2 p(\%)$ \\
\hline $\mathrm{Pt} / \mathrm{Ba} / \mathrm{Al}_{2} \mathrm{O}_{3}-\mathrm{CNTs}-\mathrm{SO}_{2}$ & 0.61 \\
$\mathrm{Pt} / \mathrm{Ba} / \mathrm{Al}_{2} \mathrm{O}_{3}-\mathrm{SO}_{2}$ & 2.08 \\
$\mathrm{Pt} / \mathrm{Ba} / \mathrm{Al}_{2} \mathrm{O}_{3}-\mathrm{CNTs}-\mathrm{SO}_{2}-\mathrm{H}_{2}$ & 0.14 \\
$\mathrm{Pt} / \mathrm{Ba} / \mathrm{Al}_{2} \mathrm{O}_{3}-\mathrm{SO}_{2}-\mathrm{H}_{2}$ & 1.04 \\
\hline
\end{tabular}

ure 7(a) shows that when $\mathrm{Pt} / \mathrm{Ba} / \mathrm{Al}_{2} \mathrm{O}_{3}$-CNTs was exposed to NO $\left(500 \times 10^{-6}\right)-2 \% \mathrm{O}_{2}$ in Ar at $200{ }^{\circ} \mathrm{C}$ for $0.5 \mathrm{~h}$, the characteristic band of bidentate nitrite at ca. $1247 \mathrm{~cm}^{-1}$ was observed [24]. The band intensity gradually weakened with increasing temperature, and the nitrate peak at $1334 \mathrm{~cm}^{-1}$ became progressively more intense. A broad peak at $1635 \mathrm{~cm}^{-1}$ was assigned to bridging/chelating bidentate nitrate at surface Ba sites [25], and a blue shift was observed with increasing temperature [26]. Thus, the $\mathrm{NO}_{x}$ storage process depended strongly on temperature. $\mathrm{NO}_{x}$ storage occurred via both nitrate and nitrite at $<200{ }^{\circ} \mathrm{C}$, but solely by nitrate at $>250^{\circ} \mathrm{C}$.

When $\mathrm{SO}_{2}\left(150 \times 10^{-6}\right)$ was introduced to the feed gas, a new peak at $c a .1166 \mathrm{~cm}^{-1}$ was detected (Fig. 7(b)), which may have been the chelating bidentate $\mathrm{S}-\mathrm{O}$ vibration of bulk sulfate [27]. The peak intensity gradually increased with increasing time, and reached a maximum after $0.5 \mathrm{~h}$ (Fig. 7 (c)). Peaks of nitrate species at $c a .1472 \mathrm{~cm}^{-1}$ and bridging/chelating bidentate nitrate at $c a .1635 \mathrm{~cm}^{-1}$ were still observed, suggesting that the formation of sulfate species had no effect on the $\mathrm{NO}_{x}$ stor-
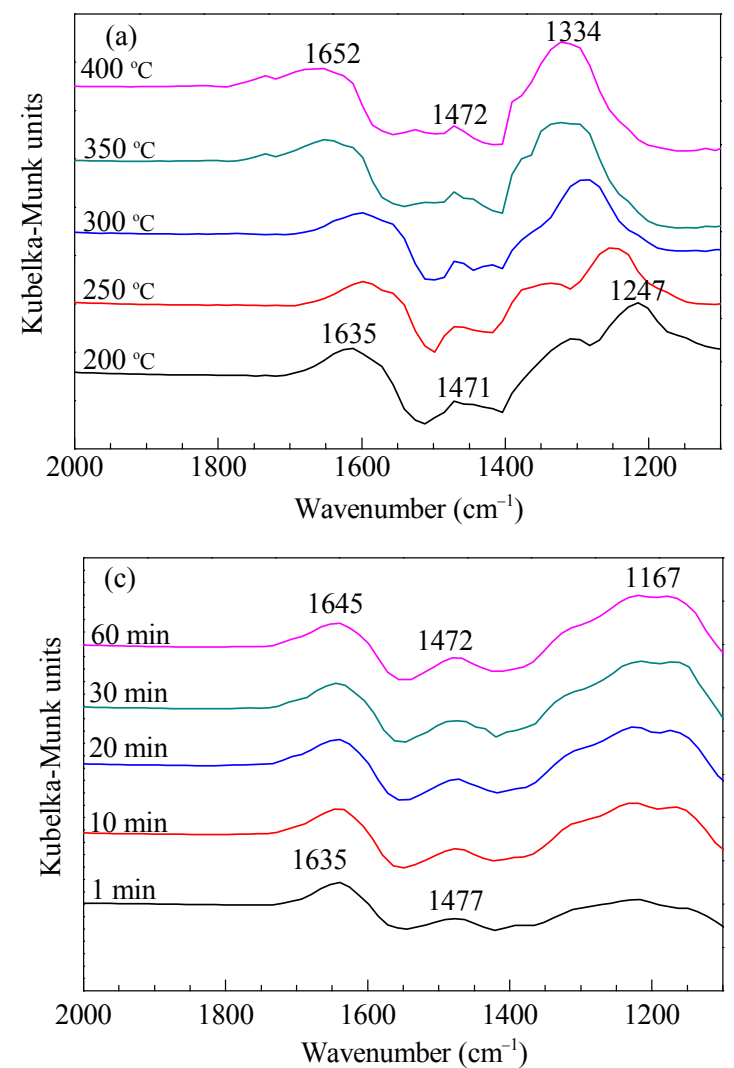

age process.

The regeneration of $\mathrm{Pt} / \mathrm{Ba} / \mathrm{Al}_{2} \mathrm{O}_{3}-\mathrm{CNTs}-\mathrm{SO}_{2}$ was performed in $3.5 \% \mathrm{H}_{2}$ at $400{ }^{\circ} \mathrm{C}$, and the results are shown in Fig. 7 (d). The sulfate species peak at $c a .1166 \mathrm{~cm}^{-1}$ had largely disappeared, indicating that $\mathrm{Pt} / \mathrm{Ba} / \mathrm{Al}_{2} \mathrm{O}_{3}-\mathrm{CNTs}$ possessed good regeneration ability.

\section{Conclusions}

$\mathrm{Pt} / \mathrm{Ba} / \mathrm{Al}_{2} \mathrm{O}_{3}-\mathrm{CNTs}$ was prepared and used in $\mathrm{NO}_{x}$ storage and reduction. The catalyst exhibited higher resistance to $\mathrm{SO}_{2}$ poisoning, and regeneration ability in $\mathrm{NO}_{x}$ reduction, compared with $\mathrm{Pt} / \mathrm{Ba} / \mathrm{Al}_{2} \mathrm{O}_{3}$. The superior performance was ascribed to the favorable $\mathrm{SO}_{2}$ adsorption ability of CNTs, and their resistance against oxidation. This inhibited the oxidation of $\mathrm{SO}_{2}$ to $\mathrm{SO}_{3}$ under oxygen-rich conditions. The presence of $\mathrm{SO}_{2}$ had no obvious effect on the NSR process. $\mathrm{Al}_{2} \mathrm{O}_{3}$-CNTs is an excellent NSR support in the presence of $\mathrm{SO}_{2}$, and is an alternative for new sulfur-resistant NSR catalysts.

\section{References}

[1] Zuo Y Q, Han L N, Bao W R, Chang L P, Wang J C. Chin J Catal (左永 权, 韩丽娜, 鲍卫仁, 常丽萍, 王建成. 催化学报), 2013, 34: 1112

[2] Easterling V, Ji Y Y, Crocker M, Ura J, Theis J R, McCabe R W. Catal Today, 2010, 151: 338

[3] Roy S, Baiker A. Chem Rev, 2009, 109: 4054

[4] Amberntsson A, Skoglundh M, Ljungström S, Fridell E. J Catal,
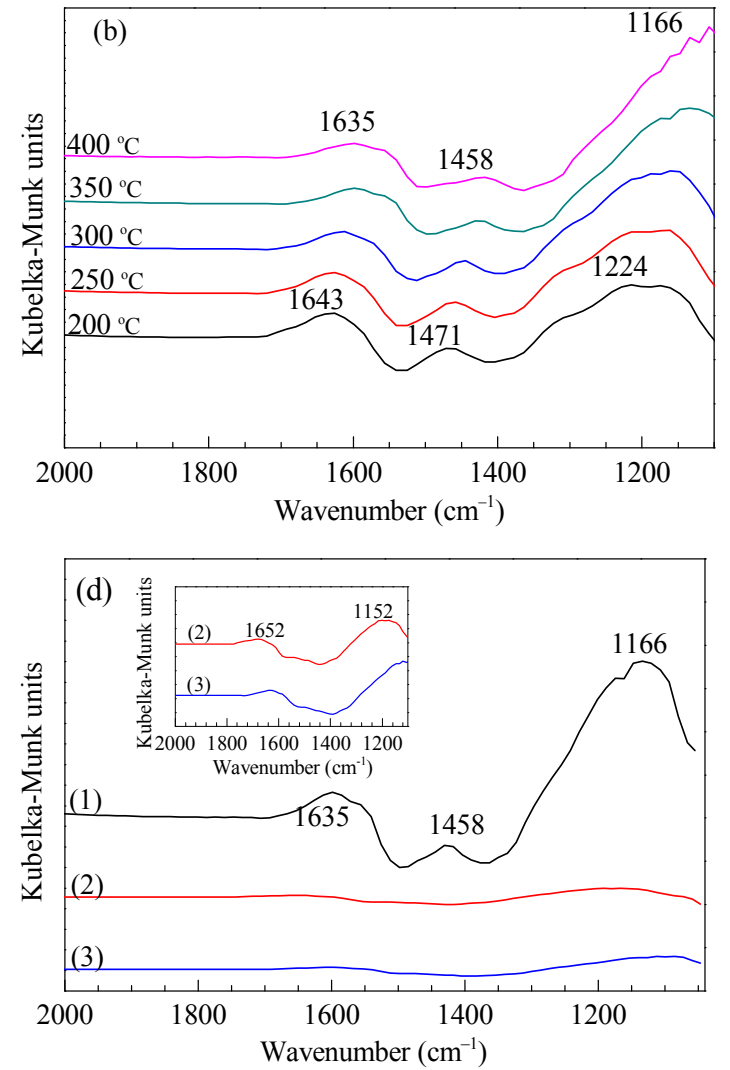

Fig. 7. In-situ DRIFTS spectra of Pt/Ba/ $\mathrm{Al}_{2} \mathrm{O}_{3}$-CNTs after exposure to (a) $\mathrm{NO}\left(500 \times 10^{-6}\right)-\mathrm{O}_{2}$ in $\mathrm{Ar}$ for $0.5 \mathrm{~h}$ at different temperatures; (b) $\mathrm{NO}(500 \times$ $\left.10^{-6}\right)-2 \% \mathrm{O}_{2}-\mathrm{SO}_{2}\left(150 \times 10^{-6}\right)$ in Ar for $0.5 \mathrm{~h}$ at different temperatures, (c) $\mathrm{NO}\left(500 \times 10^{-6}\right)-2 \% \mathrm{O}_{2}-\mathrm{SO}_{2}\left(150 \times 10^{-6}\right)$ in Ar at $200{ }^{\circ} \mathrm{C}$ for different time and (d) $\mathrm{SO}_{2}\left(150 \times 10^{-6}\right)$ at $400{ }^{\circ} \mathrm{C}$ for $0.5 \mathrm{~h}$, and then reduced by $\mathrm{H}_{2}$ for different time. 


\title{
Graphical Abstract
}

Chin. J. Catal., 2013, 34: 2271-2276 doi: 10.1016/S1872-2067(12)60745-1

\section{Alumina-carbon nanotube supports for sulfur-resistant regenerable Pt-based catalysts in $\mathrm{NO}_{x}$ reduction}

Lilong Jiang*, Yuling Wang, Xian Liu, Yanning Cao, Kemei Wei Fuzhou University

$\mathrm{Pt} / \mathrm{Ba} / \mathrm{Al}_{2} \mathrm{O}_{3}-\mathrm{CNT}$ s exhibited high resistance against sulfur poisoning, and good regeneration ability in $\mathrm{NO}_{x}$ removal, in comparison with $\mathrm{Pt} / \mathrm{Ba} / \mathrm{Al}_{2} \mathrm{O}_{3}$.

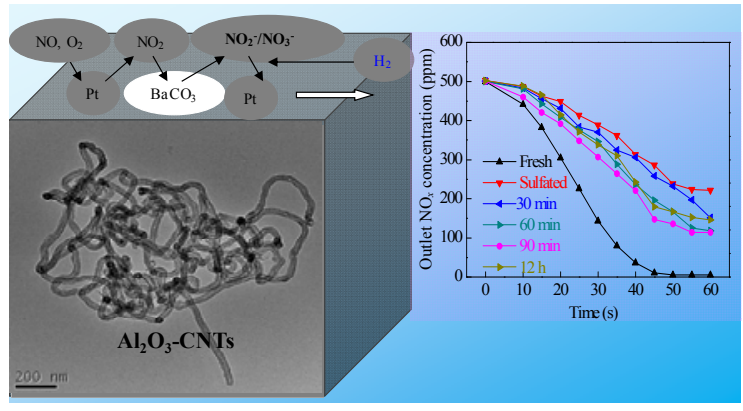

16] [16] Wang S J, Zhu W X, Liao D W, Ng C F, Au C T. Catal Today, 2004, 93-95: 711

[17] De Jong K P, Geus J W. Catal Rev-Sci Eng, 2000, 42: 481

[18] Luo J Z, Gao L Z, Leung Y L, Au C T. Catal Lett, 2000, 66: 91

[19] Ma Z X, Yang H S, Li Q, Zheng J W, Zhang X B. Appl Catal A, 2012, 427-428: 43

[20] Wang X Y, Chen Z L, Luo Y J, Jiang L L, Wang R H. Sci Rep, 2013, 3: 1559

[21] Santucci S, Picozzi S, Di Gregorio F, Lozzi L, Cantalini C, Valentini L, Kenny J M, Delleg B. J Chem Phys, 2003, 119: 10904

[22] Imagawa H, Takahashi N, Tanaka T, Matsunaga S, Shinjoh H. Appl Catal B, 2009, 92: 23

[23] Zhu H Q, Qin Z F, Shan W J, Shen W J, Wang J G. J Catal, 2004, 225 : 267

[24] Zou Z Q, Meng M, Tsubaki N, He J J, Wang G, Li X G, Zhou X Y.J Hazard Mater, 2009, 170: 118

[25] Pieta I S, García-Diéguez M, Herrera C, Larrubia M A, Alemany L J.J Catal, 2010, 270: 256

[26] Castoldi L, Lietti L, Forzatti P, Morandi S, Ghiotti G, Vindigni F. J Catal, 2010, 276: 335

[27] Abdulhamid H, Fridell E, Dawody J, Skoglundh M. J Catal, 2006, 241: 200

15] Kongkanand A, Vinodgopal K, Kuwabata S, Kamat P V.J Phys Chem $B, 2006,110: 16185$

\section{碳纳米管-氧化铝: 高抗硫及再生性能的Pt基催化剂载体 及在NO 还原反应中的应用}

\author{
江莉龙 ${ }^{*}$, 王玉玲, 刘弦, 曹彦宁, 魏可镁 \\ 福州大学化肥催化剂国家工程研究中心, 福建福州 350002
}

摘要: 通过乙炔在 $\mathrm{Al}_{2} \mathrm{O}_{3}$ 上的分解制备碳纳米管-氧化铝 $\left(\mathrm{Al}_{2} \mathrm{O}_{3}-\mathrm{CNTs}\right)$ 载体. 采用浸渍法, 分别制备了 $\mathrm{Pt} / \mathrm{Ba} / \mathrm{Al}_{2} \mathrm{O}_{3}-\mathrm{CNTs}$ 和 $\mathrm{Pt} / \mathrm{Ba} / \mathrm{Al}_{2} \mathrm{O}_{3}$ 催化剂. 利用XRD, SEM, TEM, 低温 $\mathrm{N}_{2}$ 物理吸附, XPS和in-situ DRIFTS等手段对催化剂的物化性质进行了表征. 结果 表明, 在 $\mathrm{SO}_{2}$ 存在下的 $\mathrm{NO}_{x}$ 还原反应中, $\mathrm{Pt} / \mathrm{Ba} / \mathrm{Al}_{2} \mathrm{O}_{3}-\mathrm{CNTs}$ 比 $\mathrm{Pt} / \mathrm{Ba} / \mathrm{Al}_{2} \mathrm{O}_{3}$ 具有更高的抗 $\mathrm{SO}_{2}$ 性能和再生性能. In-situ DRIFTS表明 $\mathrm{SO}_{2}$ 的存在对 $\mathrm{NO}_{x}$ 储存还原的途径没有影响.

关键词：碳纳米管；氮氧化物净化；二氧化硫中毒；再生

收稿日期: 2013-09-14. 接受日期: 2013-10-21. 出版日期: 2013-12-20.

*通讯联系人.电话: (0591)83731234-8201; 传真: (0591)83707796; 电子信箱:j11@fzu.edu.cn

基金来源：国家自然科学基金(21073039); 福建省自然科学基金(2013J05025).

本文的英文电子版由Elsevier出版社在ScienceDirect上出版(http://www.sciencedirect.com/science/journal/18722067). 